\title{
METHODS FOR INOCULATION WITH Fusarium guttiforme AND GENETIC RESISTANCE OF PINEAPPLE (Ananas comosus var. comosus) ${ }^{1}$
}

\author{
WANDREILLA MOREIRA GARCIA ${ }^{2 *}$, WILLIAN KRAUSE ${ }^{2}$, DEJÂNIA VIEIRA DE ARAÚJO ${ }^{2}$, ISANE VERA \\ KARSBURG $^{2}$, RIVANILDO DALLACORT ${ }^{2}$
}

\begin{abstract}
The objective of this work was to evaluate Fusarium guttiforme inoculation methods and genetic resistance of pineapple accessions. Thus, three experiments were conducted: pathogen inoculation of different leaf types $(B, D$ and $F)$ of pineapple (1), pathogen inoculation of pineapple cuttings and detached $D$ leaves (2), and identification of resistance to fusariosis in 19 pineapple accessions (3) sampled in the State of Mato Grosso, Brazil. The cultivars Pérola (susceptible to fusariosis) and BRS-Vitória (resistant to fusariosis) were used as controls. The fusariosis severity was evaluated at 10, 15, 20, 25 and 30 days after inoculation with F. guttiforme. The lesion diameters (severity level) were used in order to calculate the area under the disease progress curve (AUDPC). The inoculation of detached $D$ leaves was the most efficient, fast and inexpensive method, and the one that most satisfactorily reproduced the disease symptoms. The period of 10 to 20 days after inoculation of the $D$ detached leaves with the pathogen is the most suitable to evaluate the resistance of pineapple accessions to fusariosis. The lowest lesion area and AUDPC was found in the accession 1, in all evaluations. Thus, the accession 1 can be used in pineapple breeding programs for resistance to fusariosis.
\end{abstract}

Keywords: Ananas comosus var. comosus. Genetic resistance. Fusariosis.

\section{MÉTODOS DE INOCULAÇÃO DE Fusarium guttiforme E RESISTÊNCIA GENÉTICA EM ABACAXIZEIROS (Ananas comosus var. comosus)}

\begin{abstract}
RESUMO - Objetivou-se avaliar métodos de inoculação de Fusarium guttiforme e a resistência genética em acessos de abacaxizeiro. Para isso, foram realizados três experimentos, a saber: 1- inoculações em folhas de abacaxizeiro dos tipos $B, \quad D$ e F; 2- inoculações em folhas "D" destacadas e em mudas de abacaxizeiro e 3- identificação de resistência à fusariose em 19 acessos de abacaxizeiros coletados no estado de Mato Grosso. As cultivares Pérola (suscetível à fusariose) e BRS-Vitória (resistente à fusariose) foram utilizadas como testemunhas. As avaliações de severidade da fusariose foram conduzidas aos 10, 15, 20, 25 e 30 dias, após inoculação de $F$. guttiforme. Foram utilizados os diâmetros das lesões (quantificação da severidade), para o cálculo da área abaixo da curva de progresso da doença (AACPD). Dentre os métodos avaliados, observou-se que o método de inoculação em folhas $D$ destacadas foi o mais eficiente, rápido e de baixo custo, além de reproduzir satisfatoriamente os sintomas da doença. O período indicado para avaliar acessos resistentes a fusariose é entre 10 e 20 dias após inoculação do patógeno, em folhas $D$ destacadas. No acesso 1 foi observada menor área de lesão e AACPD, em todas as avaliações realizadas. Este acesso pode ser recomendado para compor programas de melhoramento do abacaxizeiro visando resistência à fusariose.
\end{abstract}

Palavras-chave: Ananas comosus var. comosus. Resistência genética. Fusariose.

\footnotetext{
*Corresponding author

${ }^{1}$ Received for publication in $05 / 20 / 2015$; accepted in 08/26/2016.

Paper extracted from the master thesis of the first author. Research supported by FAPEMAT and CNPq.

${ }^{2}$ Department of Agronomy, Universidade do Estado de Mato Grosso, Tangará da Serra, MT, Brazil; wan_moreira@hotmail.com, krause@unemat.br, dejania@unemat.br, isane9@yahoo.com.br, rivanildo@unemat.br.
} 


\section{INTRODUCTION}

Pineapple [Ananas comosus (L.) Merril var. comosus Coppens and Leal] belongs to the Bromeliaceae family and is indigenous to South America. This fruit species of tropical and subtropical climate has great economic and social importance in more than 70 countries (CRESTANI et al., 2010). Brazil is the largest world producer of pineapple, which had a production of $1,762,938 \mathrm{Mg}$ in 2014 (IBGE, 2016). The pineapple fruit presents good organoleptic characteristics and its cultivation has satisfactory economic viability (PONCIANO et al., 2006).

Some factors have hindering the achievement of higher yields of pineapple in Brazil. The occurrence of diseases, for example, is a phytosanitary barrier. Fusariosis is the main disease of pineapple in Brazil, which was reported for the first time in the State of São Paulo by Kimati and Tokeshi (1964). Fusariosis is caused by the fungus Fusarium guttiforme (NIREMBERG; O'DONNELL, 1998), which enters host plants through natural openings or injuries in cuttings, fruits, leaves and roots, causing losses of 30 to $40 \%$ of fruits and $20 \%$ of cuttings (VERZIGNASSI et al., 2009).

The control of fusariosis requires integration of various cultural practices such as the use of healthy propagative material and constant inspection at planting, removing the infected material and performing chemical control. These practices contribute to enable the production in periods that favors the disease, i.e., periods with average temperature between 24 to $25^{\circ} \mathrm{C}$. However, this practices have high cost and the chemical control may cause damage to the environment (VENTURA; COSTA, 2002).

The use of genetic resistant materials has been a measure of great potential for disease control in pineapple, reducing production costs and yield losses. The use of methods for inoculation with pathogens that are efficient in express the disease symptoms is necessary for assess resistance sources in germplasm. Some inoculation methods in incubation conditions have already been successfully used to identify genetic resistance sources in pineapple (OLIVEIRA; LEITE; PEREIRA, 2011). Giacomelli, Roessing and Teófilo Sobrinho (1969) conducted the first studies regarding pineapple resistance to fusariosis, assessing the pathogen incidence in fruits. Although efficient, this method is slow, since the crop cycle lasts on average 18 months. Therefore, Souto and Matos (1978) developed a method for evaluation through artificial inoculation of pineapple slips, reducing the evaluation time to six months. Santos, Matos and Cabral (2001a) reduced this time with inoculation of pineapple leaves.

Thus, the objective of this work was to evaluate Fusarium guttiforme inoculation methods and genetic resistance of pineapple accessions, aiming the use of potentials resistance sources in breeding programs.

\section{MATERIAL AND METHODS}

\section{Accessions and isolates used in the experiments}

The pineapple accessions used in this work were from collections that were carried out in pineapple farms of the State of Mato Grosso, Brazil, and from micropropagation by in vitro tissue culture (Table 1), which formed the active germplasm bank (AGB).

Twenty pineapple slips per accession were planted in simple rows, with spacing of $1.2 \mathrm{~m} \mathrm{x} 0.4$ $\mathrm{m}$, in the experimental area of the Mato Grosso State University, Tangara da Serra, Mato Grosso, Brazil $\left(14^{\circ} 39^{\prime} \mathrm{S}, 57^{\circ} 25^{\prime} \mathrm{W}\right.$ and altitude of $\left.321 \mathrm{~m}\right)$. The soil of the region was classified as Oxisol (distroferric Red Latosol - SiBCS) of clayey texture (clay content above $40 \%$ ), and the relief as plain to slightly wavy. The soil chemical analysis of the layer $0-20 \mathrm{~cm}$ presented $\mathrm{pH} \quad\left(\mathrm{CaCl}_{2} \quad 0.01 \mathrm{~mol} \mathrm{~L} \mathrm{~L}^{-1}\right)$ of 4.4, $54 \mathrm{mmol}_{\mathrm{c}} \mathrm{dm}^{-3}$ of $\mathrm{H}+\mathrm{Al}, 2 \mathrm{mmol}_{\mathrm{c}} \mathrm{dm}^{-3}$ of $\mathrm{Ca}$, $1 \mathrm{mmol}_{\mathrm{c}} \mathrm{dm}^{-3}$ of $\mathrm{Mg}, 0.3 \mathrm{mmol}_{\mathrm{c}} \mathrm{dm}^{-3}$ of $\mathrm{K}$, $1 \mathrm{mg} \mathrm{dm}^{-3}$ of $\mathrm{P}$ (Resin) and $6 \%$ of base saturation. Soil liming and fertilization at planting and topdressing were performed according to the soil analysis, following the recommendations of Cunha, Cabral and Souza (1999).

The Fusarium guttiforme isolate used in this work was obtained by monosporic culture. The isolates were maintained in PDA medium (potato, dextrose and agar), stored in a BOD incubator at $25^{\circ}$ $\mathrm{C}$, with a 12-hour photoperiod, and in test tubes with sand, stored in a refrigerator at $4^{\circ} \mathrm{C} \pm 2^{\circ} \mathrm{C}$ (GARCIA et al., 2015). 
W. M. GARCIA et al.

Table 1. Accessions of Ananas comosus var. comosus, sampled in the State of Mato Grosso, Brazil.

\begin{tabular}{lll}
\hline Accessions & Origin & Spinescence \\
\hline 1 & Tangara da Serra $^{1}$ & No \\
2 & Tangara da Serra $^{1}$ & No \\
3 & Tangara da Serra $^{1}$ & Yes \\
4 & Tangara da Serra $^{1}$ & No \\
5 & Nova Guarita $^{1}$ & Yes \\
6 & Claudia $^{1}$ & Yes \\
7 & Colider $^{1}$ & Yes \\
8 & Nova Guarita $^{1}$ & Yes \\
9 & Colider $^{1}$ & No \\
10 & Tangara da Serra $^{2}$ & No \\
11 & Tangara da Serra $^{2}$ & No \\
12 & Tangara da Serra $^{2}$ & No \\
13 & Tangara da Serra $^{1}$ & Yes \\
14 & Terra Nova do Norte $^{1}$ & No \\
15 & Terra Nova do Norte $^{1}$ & No \\
16 & Terra Nova do Norte $^{1}$ & Yes \\
17 & Terra Nova do Norte $^{1}$ & Yes \\
\hline 18 & Terra Nova do Norte $^{1}$ & Yes \\
19 & Tangara da Serra $^{1}$ & Yes \\
\hline BRS-Vitoria (Resistant) & Tangare da Serra $^{1}$ & No \\
Perola (Susceptible) & Terra Nova do Norte $^{1}$ & Yes \\
\hline
\end{tabular}

${ }^{1}$ cuttings (slips); ${ }^{2}$ in vitro tissue culture.

Experiment 1 - Pathogen inoculation of different leaf types $(B, D$ and $F)$ of pineapple

Leaf types $B, D$ and $F$ were evaluated in order to identify the one that best reproduces the fusariosis symptoms and the most efficient for evaluations of genetic resistance. The pineapple leaves are classified according to their position and function in the plant. The $A$ leaves are the ones in the plant base and the $F$ leaves are the youngest ones in the apex. The others leaf types are classified according to their angulation. The $D$ leaves form an angle of $45^{\circ}$ considering the ground level $(\mathrm{x})$ and the plant axis (y) in a Cartesian plane; the edges of its lower part are perpendicular to the base and it is easily detached from the plant (CABRAL; FERREIRA; MATOS, 1999). The $B$ leaves are the ones above the $D$ leaves and below the $A$ leaves. The leaves used in this experiment were the $B, D$ and $F$, which were detached at 270 days after planting, when the plant size was ideal for floral induction. The leaves were then taken to the laboratory, sterilized in alcohol $70 \%$ and sodium hypochlorite at $2 \%$ for two minutes, and rinsed three times in sterile distilled water.

The stored pathogen was transferred to Petri dishes containing a culture medium (PDA), and sterilized toothpicks were placed on this medium. The Petri dishes with toothpicks were maintained in a BOD incubator at $25^{\circ} \mathrm{C}$, with a 12 -hour photoperiod for 10 days. The pathogen was inoculated by the toothpick inoculation method, inserting toothpicks with pathogen structures in the leaves $(B, D$ and $F)$ at five centimeters from the leaf base (SANTOS; MATOS; CABRAL, 2001a; GARCIA et al., 2015). Non-infected toothpicks were dipped in sterile distilled water and used as negative control. After inoculation, the leaves were placed in clear polyethylene bags with cotton wool soaked in sterile distilled water and maintained in a BOD incubator at $25^{\circ} \mathrm{C}$, with a 12 -hour photoperiod.

A completely randomized design, in a $2 \times 3$ factorial arrangement (two cultivars $x$ three leaf types), was used with five replications. Each plot consisted of one leaf. The cultivars used were the Pérola (susceptible) and BRS-Vitória (resistant). The disease severity was evaluated at 15 days after inoculation (DAI), by measuring the diameter $\left(\mathrm{cm}^{2}\right)$ of the lesion caused by the pathogen in two opposite axes (CAMARGO; BARACHO, 1977).

\section{Experiment 2 - Pathogen inoculation of pineapple cuttings and detached $D$ leaves}

After identifying the type of leaf that best showed the symptoms and signs of the pathogen, the experiment 2 were conducted to compare the response of the cuttings and detached $D$ leaves to the pathogen inoculation.

The plants were obtained by tissue culture, which were acclimatized according to the method described by Souza Júnior, Barboza and Souza (2001). Planting was carried out in polyethylene bags $(10 \times 8 \mathrm{~cm})$ containing a sterile substrate $\left(\right.$ Plantmax $\left.^{\circledR}\right)$. The plants reached an average size of $15 \mathrm{~cm}$ after 90 days of acclimatization. During this period, foliar fertilizations were performed once a week using a fertilizer diluted in water (Platon- $25^{\circledR}$ at $2,0 \mathrm{~mL} \mathrm{~L}^{-1}$ ).

After acclimatization, the plants were inoculated with F. guttiforme (Souto and Matos, 1978). The base of the cuttings was injured and they were immersed in a spore suspension (105 conidia $\mathrm{mL}^{-1}$ ) for three minutes. The control was carried out by immersing lesioned plants in 
distilled water. Once inoculated, the plants were transplanted to polyethylene bags $(10 \times 20 \mathrm{~cm})$ containing a mix of soil and washed sand (3:1), then, dolomitic lime $\left(2 \mathrm{~kg} \mathrm{~m}^{3}\right)$, superphosphate $\left(1 \mathrm{~kg} \mathrm{~m}^{3}\right)$ potassium chloride $\left(0.5 \mathrm{~kg} \mathrm{~m}^{3}\right)$ (LIMA; CUNHA, 2004) and cattle manure $\left(20 \% \mathrm{v} \mathrm{v}^{-1}\right)$ were added to this mix. The plants were maintained in a greenhouse with irrigation twice a day and average temperature of $25^{\circ} \mathrm{C}$ for 90 days. After this period, the incidence of the disease was evaluated by the presence (susceptible) and absence (resistant) of symptoms of fusariosis, represented by the exudation of resin, which is a symptom and a sign of the pathogen in the plant (SOUTO; MATOS, 1978).

The $D$ leaves were detached at 270 days after planting, when the plant size was ideal for floral induction. The leaves were then taken to the laboratory, sterilized in alcohol $70 \%$ and sodium hypochlorite at $2 \%$ for two minutes, and rinsed three times in sterile distilled water.

The inoculation of $D$ leaves with the pathogen by the toothpick method was carried out as described in the first experiment. The incidence of the disease was evaluated at 15 days after inoculation by the presence (susceptible) or absence (resistant) of symptoms of fusariosis.

A completely randomized design, in a $2 \times 2$ factorial arrangement (plant/leaf $\mathrm{x}$ cultivar), was used with five replications. Each plot consisted of one plant/leaf, which had one replication. The cultivars used were the Pérola (susceptible) and $B R S$-Vitória (resistant).

\section{Experiment 3 - Identification of resistance to fusariosis in 19 pineapple accessions}

Nineteen pineapple accessions were collected in farms in different production areas of Mato Grosso State (Table 1). The $D$ leaves were detached at 270 days after planting, when the plant size was ideal for floral induction. The leaves were then taken to the laboratory, sterilized in alcohol $70 \%$ and sodium hypochlorite at $2 \%$ for two minutes, and rinsed three times in sterile distilled water.

The stored pathogen was transferred to Petri dishes containing a culture medium (PDA) and sterilized toothpicks were placed on this medium. The Petri dishes with toothpicks were maintained in a BOD incubator at $25^{\circ} \mathrm{C}$, with a 12-hour photoperiod for 10 days. The pathogen was inoculated by the toothpick inoculation method, inserting toothpicks with pathogen structures in the leaves at five centimeters from the leaf base (SANTOS; MATOS; CABRAL, 2001a; GARCIA et al., 2015). Non-infected toothpicks were dipped in sterile distilled water and used as negative control. After inoculation, the leaves were placed in clear polyethylene bags with cotton wool soaked in sterile distilled water and maintained in a BOD incubator at $25^{\circ} \mathrm{C}$, with a 12-hour photoperiod. The disease severity was evaluated by measuring the area $\left(\mathrm{cm}^{2}\right)$ of the lesion caused by the pathogen at 10, 15, 20, 25 and 30 days after inoculation. The severity data was used to calculated the area under the disease progress curve (AUDPC) (CAMPBELL; MADDEN, 1990).

A completely randomized design with five replications was used, with each plot consisting of one pineapple $D$ leaf, and considering each leaf as a replication.

The identification of the pathogen was conducted at the end of each experiment, by isolation, using the plant material assessed and by observation of the structures in an optical microscope.

\section{Statistical analysis}

The data of the experiments 1 and 3 were subjected to analysis of variance and comparison of means by the Scott-Knott test at 5\% probability. The evaluation periods in the experiment 3 were analyzed by regression and Spearman's correlation between the lesion areas and the AUDPC. The data of the experiment 1 and 3 were processed to $\sqrt{x}_{\mathrm{x}}+0.5$. All analysis was performed using the statistical software SISVAR (FERREIRA, 2011).

\section{RESULTS AND DISCUSSION}

\section{Experiment 1 - Pathogen inoculation of different leaf types $(B, D$ and $F)$ of pineapple}

The experiment 1 showed a significant interaction $(\mathrm{p} \leq 0.01)$ between types of leaves and cultivars (Table 2 ).

Table 2. Lesion area $\left(\mathrm{cm}^{2}\right)$ resulting from the Fusarium guttiforme inoculation of different leaf types of susceptible (Pérola) and resistant (BRS-Vitória) cultivars of pineapple.

\begin{tabular}{lcc}
\hline \multirow{2}{*}{ Leaf type } & \multicolumn{2}{c}{ Cultivar } \\
\cline { 2 - 4 } & Perola & BRS-Vitoria \\
\hline$B$ & $4.64 \mathrm{bA}$ & $1.50 \mathrm{aB}$ \\
$D$ & $9.66 \mathrm{aA}$ & $2.72 \mathrm{aB}$ \\
$F$ & $3.66 \mathrm{bA}$ & $2.60 \mathrm{aA}$ \\
\hline CV $(\%)$ & & 17.3 \\
\hline
\end{tabular}

Means followed by the same lowercase letter in the column and uppercase letter in the row do not differ significantly by the Scott-Knott test at $5 \%$ probability. 
The sizes of the lesions caused by $F$. guttiforme were similar in all leaf types evaluated in the cultivar BRS-Vitória, since this cultivar is resistant to fusariosis and has thicker leaf tissues (ZORZAL et al., 2008), which may have hindered the pathogen penetration into the plants. The effect of the pathogen inoculated in the cultivar Pérola was different in each leaf type. The $D$ leaves had the largest lesion area, differing from the $B$ and $F$ leaves (Table 2), presenting the typical symptoms of fusariosis with this type of inoculation. Therefore, it is the most appropriate leaf type to assess the reaction of $F$. guttiforme isolates in pineapple. Santos, Matos and Cabral (2001a) analyzed different leaf types $(A, B, C, D$ and $F)$ of the cultivar Pérola inoculated with $F$. guttiforme, and found symptoms in all inoculated leaves, however, the $D$ leaves showed the largest lesion area. They concluded that the fungus infection occurs regardless of the type or place of inoculation, and that the severity of the symptoms may vary depending on the leaf type inoculated.

Silva-Acuña, Costa and Barreto (1995) evaluated C, D and E leaves of the cultivar Pérola inoculated with $F$. guttiforme by the method of mycelial disk inoculation with injury and found $D$ leaves with larger lesions than the other leaf types, suggesting that this is the most appropriate leaf type to assess the genotype susceptibility to fusariosis
The $D$ leaves are used to assess nutritional status and growth of plants, since it is the most physiologically active leaf type (CUNHA; CABRAL; SOUZA, 1999). Thus, according to the results found in the present study, the $D$ leaves are recommended to evaluate the resistance of pineapple accessions to fusariosis, since it satisfactorily reproduces the fusariosis symptoms and provides reliable results.

\section{Experiment 2 - Pathogen inoculation of pineapple cuttings and detached $D$ leaves}

The cultivar Pérola was susceptible to fusariosis, as expected, regardless the inoculation type (detached leaves or cuttings), and the cultivar BRS-Vitória was resistant (Table 3). Thus, inoculations of detached leaves, as well as in cuttings provide consistent results for evaluations of resistance variability in pineapple. However, the inoculation of $D$ leaves is recommended, since this method had lower cost and higher efficiency for assessments of resistance sources.

Experiments with detached leaves have been frequently used because they are efficient and practical for determination of the potential of biocontrol agents and resistance of genotypes to pathogens (MACIEL et al., 2012).

Table 3. Incidence of symptoms caused by the Fusarium guttiforme fungus in cuttings and detached $D$ leaves of susceptible (Pérola) and resistant (BRS-Vitória) cultivars of pineapple.

\begin{tabular}{lcc}
\hline \multirow{2}{*}{ Cultivars } & \multicolumn{2}{c}{ Symptoms } \\
\cline { 2 - 3 } & Cuttings & Leaves \\
\hline Perola (Control) & Absente & Absente \\
Perola & Present & Present \\
BRS-Vitoria (Control) & Absente & Absente \\
BRS-Vitoria & Absente & Absente \\
\hline
\end{tabular}

F. guttiforme inoculations of pineapple detached $D$ leaves proved to be an efficient method to identify resistant accessions to this pathogen, and a method of reduced evaluation time. Other authors reported the reduced labor and contamination risk of this method (SANTOS; MATOS; CABRAL, 2001b).

\section{Experiment 3 - Identification of resistance to fusariosis in 19 pineapple accessions}

The symptoms caused by the pathogen started at 10 days after inoculation (DAI), which was the first evaluation time (Figure 1). The lesion area increased with time after inoculation, thus the largest area was found at $30 \mathrm{DAI}$.

The Spearman's coefficient of correlation showed a high correlation between the lesion area at different times and the AUDPC, with all correlations above $94 \%$ (Table 4 ). Thus, the ranking of cultivars showed no changes in the different periods of evaluation.

However, the leaf bases showed signs of decomposition at $25 \mathrm{DAI}$, which may have hindered the evaluations and generated unreliable data depending on the damage level. Therefore, evaluations of resistance to fusariosis in pineapple must be performed at 10 to 20 DAI. Thus, the $F$. guttiforme incidence and inoculation methods has been evaluated at 15 DAI of pineapple $D$ leaves, obtaining satisfactory results of resistance to fusariosis (OLIVEIRA; LEITE; PEREIRA, 2011). 


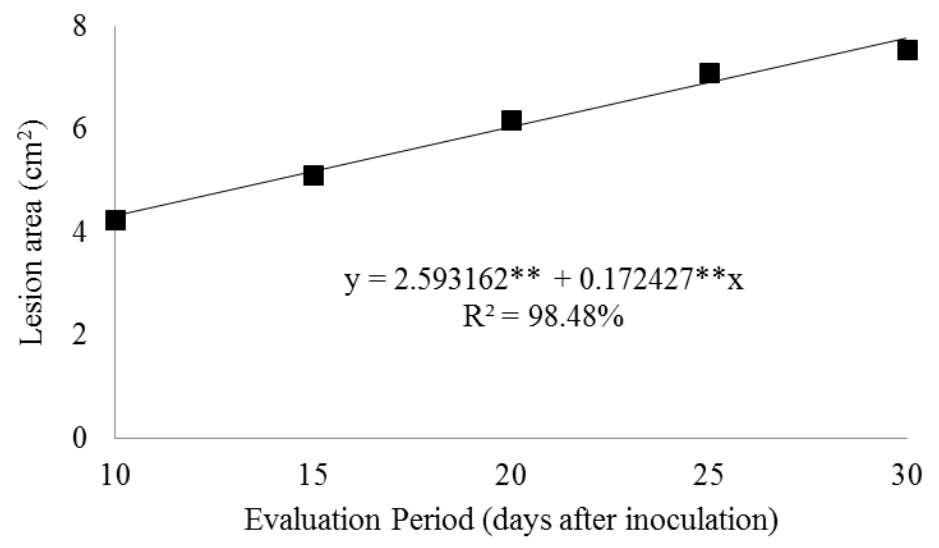

Figure 1. Lesion area caused by Fusarium guttiforme, evaluated at different times after the pathogen inoculation.

Table 4. Correlation of severity and area under the disease progress curve (AUDPC) up to 30 days after inoculation (DAI) in different pineapple accessions.

\begin{tabular}{lccccc}
\hline & 15 DAI & 20 DAI & 25 DAI & 30 DAI & AUDPC \\
\hline 10 DAI & 0.99 & 0.96 & 0.94 & 0.95 & 0.97 \\
15 DAI & - & 0.97 & 0.95 & 0.95 & 0.97 \\
20 DAI & - & - & 0.99 & 0.99 & 0.99 \\
25 DAI & - & - & - & 0.99 & 0.97 \\
30 DAI & - & - & - & - & 0.98 \\
\hline
\end{tabular}

According to the evaluation of the accession resistances, the accession 1 showed resistance in all evaluations and had the lowest AUDPC, not differing from the resistant control cultivar BRS-Vitória (Table 5).

Table 5. Fusariosis severity and area under the disease progress curve (AUDPC) in 19 pineapple accessions.

\begin{tabular}{|c|c|c|c|c|c|c|}
\hline \multirow{2}{*}{ Accessions } & \multicolumn{5}{|c|}{ Days After Inoculation (DAI) } & \multirow{2}{*}{ AUDPC } \\
\hline & $10 \mathrm{DAI}$ & 15 DAI & 20 DAI & $25 \mathrm{DAI}$ & $30 \mathrm{DAI}$ & \\
\hline 1 & $1.68 \mathrm{a}$ & $1.78 \mathrm{a}$ & $1.89 \mathrm{a}$ & $1.99 \mathrm{a}$ & $2.05 a$ & $46.07 a$ \\
\hline 2 & $3.15 \mathrm{~b}$ & $4.17 \mathrm{~b}$ & $5.07 \mathrm{~b}$ & $5.57 \mathrm{~b}$ & $6.13 \mathrm{c}$ & $93.76 b$ \\
\hline 3 & $4.52 \mathrm{c}$ & $5.43 \mathrm{c}$ & $6.18 \mathrm{c}$ & $6.98 \mathrm{c}$ & $8.24 d$ & $147.46 \mathrm{c}$ \\
\hline 4 & $3.43 \mathrm{~b}$ & $3.87 \mathrm{~b}$ & $5.05 \mathrm{~b}$ & $5.33 b$ & $5.60 \mathrm{c}$ & $111.06 \mathrm{~b}$ \\
\hline 5 & $3.44 \mathrm{~b}$ & $4.48 \mathrm{~b}$ & $6.04 \mathrm{c}$ & $6.89 \mathrm{c}$ & $7.91 \mathrm{~d}$ & $132.65 \mathrm{c}$ \\
\hline 6 & $2.99 \mathrm{~b}$ & $3.75 \mathrm{~b}$ & $5.88 \mathrm{c}$ & $7.16 \mathrm{c}$ & $8.09 \mathrm{~d}$ & $126.59 \mathrm{c}$ \\
\hline 7 & $4.19 \mathrm{c}$ & $4.99 \mathrm{c}$ & $5.65 \mathrm{c}$ & $7.01 \mathrm{c}$ & $7.78 \mathrm{~d}$ & $139.14 \mathrm{c}$ \\
\hline 8 & $3.65 b$ & $5.07 \mathrm{c}$ & $6.53 \mathrm{c}$ & $7.34 \mathrm{c}$ & $8.00 \mathrm{~d}$ & $142.14 \mathrm{c}$ \\
\hline 9 & $2.69 b$ & $3.39 \mathrm{~b}$ & $4.47 \mathrm{~b}$ & $4.66 \mathrm{~b}$ & $4.82 \mathrm{c}$ & $94.82 \mathrm{~b}$ \\
\hline 10 & $2.42 \mathrm{a}$ & $3.55 b$ & $4.75 b$ & $5.41 \mathrm{~b}$ & $5.70 \mathrm{c}$ & $100.99 b$ \\
\hline 11 & $3.69 \mathrm{~b}$ & $4.85 \mathrm{~b}$ & $5.57 \mathrm{c}$ & $6.18 \mathrm{~b}$ & $6.33 c$ & $126.47 \mathrm{c}$ \\
\hline 12 & $1.80 \mathrm{a}$ & $3.27 \mathrm{~b}$ & $4.13 b$ & $4.93 b$ & $5.08 \mathrm{c}$ & $87.83 b$ \\
\hline 13 & $5.04 \mathrm{c}$ & $5.74 \mathrm{c}$ & $6.55 c$ & $8.03 \mathrm{c}$ & $8.53 \mathrm{~d}$ & $160.74 \mathrm{c}$ \\
\hline 14 & $6.72 d$ & $7.51 \mathrm{~d}$ & $8.58 \mathrm{e}$ & $10.06 \mathrm{~d}$ & $10.48 \mathrm{e}$ & $207.35 \mathrm{~d}$ \\
\hline 15 & $5.73 \mathrm{c}$ & $6.24 \mathrm{c}$ & $7.77 \mathrm{~d}$ & $8.84 \mathrm{c}$ & $9.15 \mathrm{~d}$ & $180.12 \mathrm{c}$ \\
\hline 16 & $8.34 d$ & $9.23 \mathrm{~d}$ & $10.36 \mathrm{e}$ & $11.53 \mathrm{~d}$ & $11.80 \mathrm{e}$ & $245.38 d$ \\
\hline 17 & $5.43 \mathrm{c}$ & $6.07 \mathrm{c}$ & $7.46 \mathrm{~d}$ & $8.39 \mathrm{c}$ & $8.82 \mathrm{~d}$ & $172.39 \mathrm{c}$ \\
\hline 18 & $5.05 \mathrm{c}$ & $6.07 \mathrm{c}$ & $7.54 \mathrm{~d}$ & $8.37 \mathrm{c}$ & $8.98 \mathrm{~d}$ & $170.21 \mathrm{c}$ \\
\hline 19 & $5.23 \mathrm{c}$ & $6.44 \mathrm{c}$ & $7.17 \mathrm{~d}$ & $8.23 \mathrm{c}$ & $8.66 \mathrm{~d}$ & $170.13 \mathrm{c}$ \\
\hline BRS-Vitoria $^{1}$ & $1.72 \mathrm{a}$ & $2.33 a$ & $2.67^{\mathrm{a}}$ & $2.80 \mathrm{a}$ & $2.93 b$ & $59.17 \mathrm{a}$ \\
\hline Perola $^{1}$ & $8.49 \mathrm{~d}$ & $9.08 \mathrm{~d}$ & $10.70 \mathrm{e}$ & $13.47 \mathrm{~d}$ & $13.68 \mathrm{e}$ & $264.11 d$ \\
\hline $\mathrm{F}_{\text {calculated }}$ & $11.77 * *$ & $10.17^{* *}$ & $14.44^{* *}$ & $13.31^{* *}$ & $16.76^{* *}$ & $12.96^{* *}$ \\
\hline CV (\%) & 13.26 & 12.14 & 9.88 & 10.99 & 9.90 & 12.44 \\
\hline
\end{tabular}

**Significant by the $\mathrm{F}$ test at $1 \%$ of probability. ${ }^{1}$ Controls: BRS-Vitória (resistant) and Pérola (susceptible). Means followed by the same lowercase letter in the column do not statistically differ by the Scott-Knott test at 5\% probability. 
The accessions 14 and 16 showed the highest disease severity in all periods evaluated and largest AUDPC, similar to the susceptible cultivar Pérola. Thus, the non-spinescent accession 1 can be used as resistance source in pineapple breeding programs for resistance to fusariosis.

\section{CONCLUSIONS}

Inoculations of detached $D$ leaves satisfactorily reproduce the symptoms of fusariosis and are more efficient for evaluations of genetic resistance in pineapple accessions.

The period of 10 to 20 days after inoculation of pineapple detached $D$ leaves with the pathogen is the most suitable to evaluate the resistance of accessions to fusariosis.

The accession 1 is a potential source for pineapple resistance to fusariosis and can be used in breeding programs for resistance to diseases.

\section{ACKNOWLEDGEMENTS}

The authors thank the Mato Grosso State Research Support Foundation (FAPEMAT) for funding this research project; the Coordination for the Improvement of Higher Education Personnel (CAPES); and the Rede PRO-CENTRO-OESTE for granting the master scholarship.

\section{REFERENCES}

CABRAL, J. R. S.; FERREIRA, F. R.; MATOS, A. P. Caracterização e avaliação de germoplasma de abacaxi. Revista Brasileira de Fruticultura, Jaboticabal, 1999, v. 21, n. 3, p. 5-70.

CAMARGO, L. M. P. C. A.; BARACHO, I. R. Virulência de linhagens de Fusarium moniliforme Sheld. var. subglutinans Wr. e Rg. Summa Pytopathologica, Piracicaba, v. 3, n. 3, p. 215 - 220, 1977.

CAMPBELL, C. L.; MADDEN, L. V. Introduction to plant disease epidemiology. New York: John Wiley \& Sons, 1990. p. 552.

CRESTANI, M. et al. Das Américas para o mundo: Origem, domesticação e dispersão do abacaxizeiro. Ciência Rural, Santa Maria, v. 40, n. 6, p. 1472-1483, 2010.

CUNHA, G. A. P.; CABRAL, J. R. S.; SOUZA, L. F. S. O abacaxizeiro: cultivo, agroindústria e economia. 1. ed. Brasília, DF: Embrapa comunicação para transferência de tecnologia, 1999. p. 480 .

FERREIRA, D. F. Sisvar: a computer statistical analysis system. Ciência e Agrotecnologia, Lavras, v. 35, n. 6, p. 1039-1042, 2011.

GARCIA, W. M. et al. Comportamento in vitro do agente etiológico da fusariose e avaliação de métodos de inoculação em abacaxizeiro. Revista Caatinga, Mossoró, v. 28, n. 3, p. 263-268, 2015.

GIACOMELLI, E. J; ROESSING, J.; TEÓFILO SOBRINHO, J. Incidência da gomose numa coleção de ananas e pseudananas. Bragantia, Campinas, v. 28 , n. 1, p. 27-31, 1969.

INSTITUTO BRASILEIRO DE GEOGRAFIA E ESTATÍSTICA - IBGE. Produção Agrícola. Disponível em: <http://www.sidra.ibge.gov.br/bda/ tabela/protabl.asp? $\mathrm{c}=1612 \& \mathrm{z}=\mathrm{t} \& \mathrm{o}=11 \& \mathrm{i}=\mathrm{P}>$.

Acesso em: 8 jun. 2016.

KIMATI, H; TOKESHI, H. Nota sobre a ocorrência de Fusarium sp. causando resinose fúngica em abacaxi. Revista de agricultura, Piracicaba, v. 39, n. 3, p. 131-133, 1964.

LIMA, A. A.; CUNHA, M. A. P. Maracujá: produção e qualidade na passicultura. 1. ed. Cruz da Almas, BA: Embrapa-CNPMF, 2004. 396 p.

MACIEL, C. G. et al. Control of cylindrocladium candelabrum by trichoderma spp in eucalyptus saligna seedlings. Revista árvore, Viçosa, v. 36, n. 5, p. 825-832, 2012

NIREMBERG, H. I.; O'DONNELL, K. New Fusarium species and combinations within the Gibberella fujikuroi species complex. Micologia, Bronx, v. 90, n. 3, p. 434-458, 1998.

OLIVEIRA, M. D. M.; LEITE, L. C. N.; PEREIRA, $\mathrm{R}$. Incidência de fusariose e avaliação de métodos de inoculação de Fusarium gutiforme em folhas de abacaxizeiro. Revista Caatinga, Mossoró, v. 24, n. 1, p. 137-142, 2011.

PONCIANO, N. J. et al. Avaliação econômica da produção de abacaxi (Ananas comosus L.) cultivar pérola na região Norte Fluminense. Revista Caatinga, Mossoró, v. 19, n. 1, p. 82-91, 2006.

SANTOS, R. L. M. S.; MATOS, A. P. de; CABRAL, J. R. S. Avaliação da infecção com Fusarium subglutinans em diferentes tipos de folhas de abacaxizeiro. Magistra, Cruz das Almas, v. 13, n. 1, p. 1-50, 2001a.

SANTOS, R. L. M. S.; MATOS, A. P.; CABRAL, J. R. S. Interação entre isolados de Fusarium 
subglutinans e genótipos de abacaxizeiro mediante inoculação em mudas e em folhas destacadas. Magistra, Cruz das Almas, v. 13, n. 2, p. 67-72, $2001 b$.

SILVA-ACUÑA, R.; COSTA, A. F.; BARRETO, M. Efeito da temperatura e do tipo de folha no desenvolvimento de lesões de Fusarium subglutinans f. sp. ananas no abacaxizeiro 'Pérola'. Fitopatologia Brasileira, Brasília, v. 20, n. 3, p. 498-500, 1995.

SOUTO, G. F.; MATOS, A. P. Método para avaliar resistência à Fusarium moniliforme var. subglutinans em abacaxi. Revista Brasileira de Fruticultura, Jaboticabal, v. 2, n. 1, p. 23-30, 1978.

SOUZA JÚNIOR, E. E.; BARBOZA, S. B. S. C.; SOUZA, L. A. C. Efeitos de substratos e recipientes na aclimatação de plântulas de abacaxizeiro [Ananas comosus (L.) Merril] cv. Pérola. Pesquisa Agropecuária Tropical, Goiânia, v. 31, n. 2, p. 147-151, 2001.

VENTURA, J. A.; COSTA, H. Manejo integrado das doenças de fruteiras tropicais: Abacaxi, Banana e Mamão. In: ZAMBOLIM, L. (Eds.). Manejo integrado: fruteiras tropicais doenças e pragas. Viçosa: UFV, 2002. 2. ed., cap. 9, p. 279-352.

VERZIGNASSI, J. R. et al. Fusariose do abacaxizeiro no Pará. Summa Phytopathologica, São Paulo, v. 35, n. 4, p. 329-330, 2009.

ZORZAL, P. B. et al. Análise morfológica e bioquímica comparativa da resistência a fusariose em abacaxizeiro. In: CONGRESSO BRASILEIRO DE FRUTICULTURA， 20，2008， Vitória. Anais... Vitória: Sociedade Brasileira de Fruticultura, 2008. 